\title{
Phenotypic traits of sand lizard (Lacerta agilis) and the environmental factor effects
}

\author{
Ivan Blokhin, Natalya Veselova, and Gennady Blokhin
}

Russian State Agrarian University - Moscow Timiryazev Agricultural Academy, Department of Zoology, 127550, 44, Timiryazevskaya st., Moscow, Russian Federation

\begin{abstract}
The comparative analysis of the variability of the sand lizard's (Lacerta agilis) phenotypic traits was carried out. Lizards were trapping in four different localities. 12 morphometric characters and 22 scaling parameters were included in controlled traits; comparisons of populations were performed using Student's t-test and discriminant analysis. Lizards were captured in the village Yamnoye, Voronezh Region, the village Verkhnekardail'skiy in the Volgograd Region, and in the villages Sredniy and Poperechnyy of the Stavropol Territory. The village Yamnoye is experiencing the greatest anthropogenic pressure due to its proximity to Voronezh city and the airport. The largest number of statistically significant differences in morphometric characters was found between lizards of the Stavropol Territory and lizards from the villages Verkhnekardail'skiy and Yamnoye, between which there were significantly low number statistically significant differences in the same characters. Sexual dimorphism was most pronounced in lizards of the locality with the highest anthropogenic load - the village Yamnoye. When analyzing the characteristics of scaly cover of lizards of closes localities in villages Yamnoye and Verkhnekardail'skiy, there were more statistically significant differences than between the lizards of the last and the most remote Stavropol Territory. When assessing the severity of sexual dimorphism in terms of scaling, statistically significant differences between males and females were observed in population lizards of the Stavropol Territory and the village Verkhnekardail'skiy. The sexual dimorphism on scaly cover in lizard population of the village Yamnoye was not revealed and a relatively reduced diversity of the scaly cover was observed. Our data indicate that the variability of various phenotypic characteristics of the sand lizard is related in different ways to the influence of environmental factors, such as the geocological position of the localities of animal reproduction, anthropogenic load.
\end{abstract}

\section{Introduction}

The traditional method for assessing the state of populations of the sand lizard (age and sex structures, population dynamics in space and time) is the analysis of phenotypic traits, such as morphometric parameters, characteristics of scaly cover and coloration. Despite the large number of articles devoted to the genetic features of the sand lizard [1-5, 23] and the 
diversity of phenotypic characteristics of this species [6-17, 22], many questions, such as the expression and formation of sexual differences, remain debatable.

The high variability on the lizard's phenotypic traits and dependence of it from ecological and geographical factors were revealed in some investigation. It is known that the body length of sand lizards increases from north to south, which is probably due to a richer food base, as in the case of other morphometric characters, and the diversity of the scaly cover increases of steppe populations in comparison with forest-steppe ones on some characteristics (the number of transverse rows of abdominal scales, the number of zygomatic scutes and their sum with the posterior nasal scutes, the number of scutes around the central temporal scutellum and the number of mandibular scutes). It is believed that the variability of climatic factors such as high temperature and low humidity during the incubation of eggs and the development of embryos are the effector factors to these traits [18-21].

Based on the foregoing, it can be expected that the effects of different ecologicalgeographical factors can control the variability of distinctive traits of lizards on various ways. In this regard, in this work, we compared the populations of the sand lizard on the parameters of morphometry and scaly cover, caught in localities differentiated by the some ecological-geographical factors.

\section{Methods}

The research was carried out in 2018-2021 on the basis of the Center for Nanobiotechnologies of the Russian State Agrarian University - Moscow Agricultural Academy named after K.A. Timiryazev. Lizards were caught in three localities - in the village Verkhnekardail'skiy in the Volgograd region $\left(51^{\circ} 05^{\prime} 02^{\prime \prime} \mathrm{N} 42^{\circ} 40^{\prime} 12^{\prime \prime} \mathrm{E}\right)$, in the village Sredniy $\left(44^{\circ} 33^{\prime} 16^{\prime \prime} \mathrm{N} 42^{\circ} 57^{\prime} 23^{\prime \prime}\right.$ E) and Poperechnyy $\left(45^{\circ} 25^{\prime} 19^{\prime \prime} \mathrm{N} 43^{\circ} 15^{\prime} 32\right.$ "E) of the Stavropol Territory, as well as in the village Yamnoye, Voronezh Region (51 ${ }^{\circ}$ $47^{\prime} 30$ "N $\left.39^{\circ} 08^{\prime} 30^{\prime} \mathrm{E}\right), 44$ individuals in total. These localities have a number of differences in ecological characteristics (Table 1). 


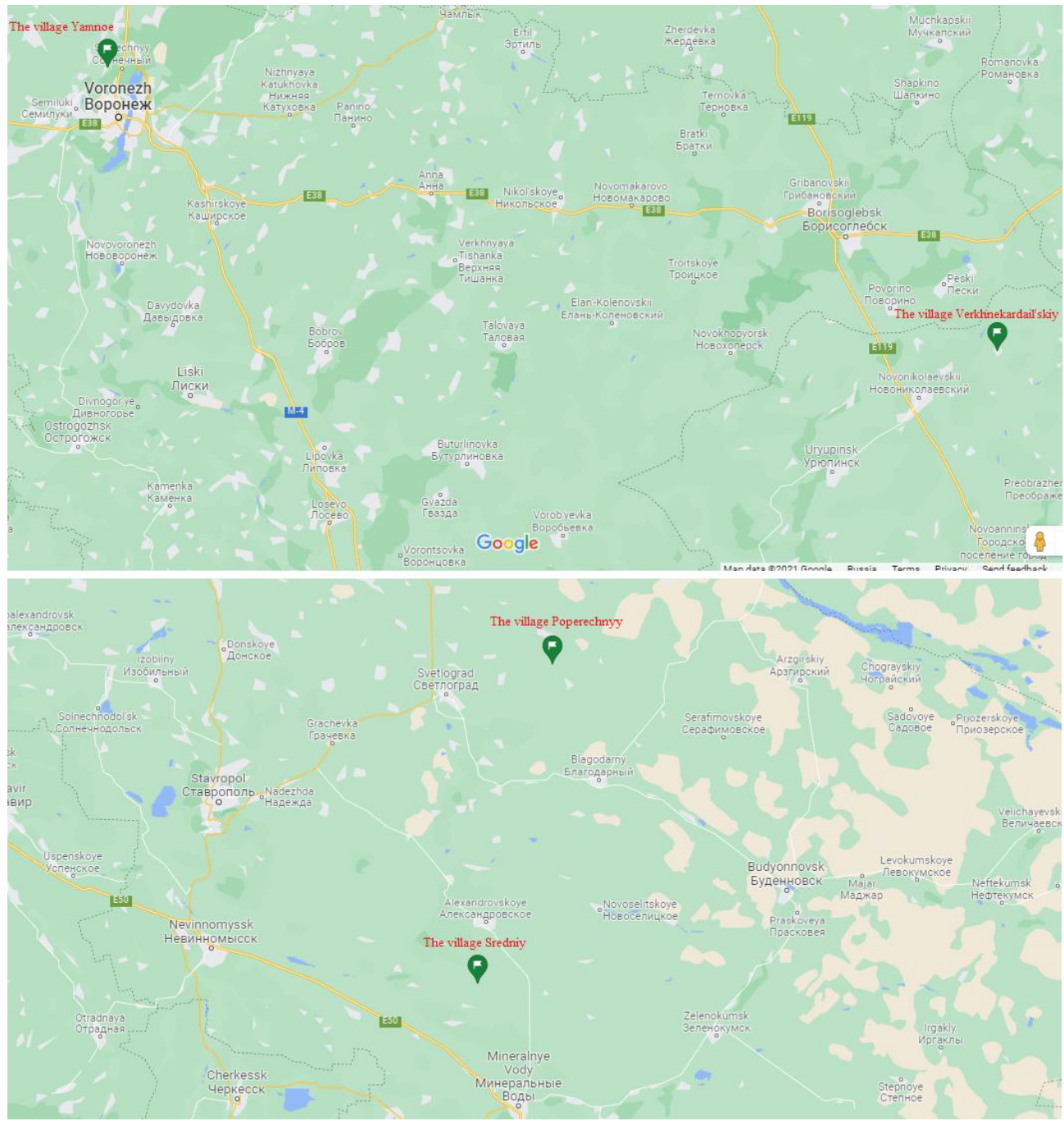

Fig. 1. Lizard collection points.

Table 1. Environmental characteristics of the locales under study.

\begin{tabular}{|l|l|l|l|}
\hline \multicolumn{1}{|c|}{ Region } & \multicolumn{1}{c|}{$\begin{array}{c}\text { Average } \\
\text { temperature }\end{array}$} & Precipitation & $\begin{array}{l}\text { Height above } \\
\text { sea level }\end{array}$ \\
\hline $\begin{array}{l}\text { Stavropol } \\
\text { Territory }\end{array}$ & $\begin{array}{l}\text { January: from - } \\
4 \text { to }-6^{\circ} \mathrm{C}, \text { July } \\
- \text { from } 22 \text { to } \\
25^{\circ} \mathrm{C} .\end{array}$ & $\begin{array}{l}\text { On the plains } \\
300-500 \mathrm{~mm} \text { per } \\
\text { year in the } \\
\text { foothills - over } \\
600 \mathrm{~mm}\end{array}$ & $\begin{array}{l}\text { About } \\
\text { meters }\end{array}$ \\
\hline $\begin{array}{l}\text { Volgograd } \\
\text { Region }\end{array}$ & $\begin{array}{l}\text { January: from - } \\
7 \text { to }-12^{\circ} \mathrm{C}, \\
\text { July }- \text { from } 28 \\
\text { to } 35^{\circ} \mathrm{C} .\end{array}$ & Up to $500 \mathrm{~mm}$ & 0 to 100 meters \\
\hline
\end{tabular}




\begin{tabular}{|l|c|l|l|}
\hline \multicolumn{1}{|c|}{ Region } & $\begin{array}{c}\text { Average } \\
\text { temperature }\end{array}$ & Precipitation & $\begin{array}{c}\text { Height above } \\
\text { sea level }\end{array}$ \\
\hline $\begin{array}{l}\text { Voronezh } \\
\text { Region }\end{array}$ & $\begin{array}{c}\text { January: } \\
-10^{\circ} \mathrm{C}, \mathrm{July}-+ \\
20^{\circ} \mathrm{C}\end{array}$ & $550-560 \mathrm{~mm}$ & 0 to 150 meters \\
\hline
\end{tabular}

The distance from the cities of the four localities is different: the village Yamnoye is located $9 \mathrm{~km}$ from the city of Voronezh and $5 \mathrm{~km}$ from the airport named after Peter I, the nearest town to the village Verkhnekardail'skiy is Borisoglebsk, $47 \mathrm{~km}$ away from it, the village Poperechnyy is $143 \mathrm{~km}$ from the city of Stavropol, and the village Sredniy $58 \mathrm{~km}$ from the Pyatigorsk city. That is, one of the differences in the localities of catching the lizards is associated with the remoteness from large urban settlements, which, apparently, can be associated with different levels of anthropogenic pressure. According to this parameter, different localities were distributed in the following descending order: the village Yamnoye in the Voronezh region, the village Verkhnekardail'skiy in the Volgograd region, the villages Sredniy and Poperechnyy in the Stavropol Territory.

In lizards, the analysis of morphometric traits (12 characteristics), 11 indices (relative traits based on morphometric indices) and scaling characteristics (22 traits) was carried out using standard techniques $[6,22,23]$.

The results were mathematically processed using the Student's $t$ test to identify statistically significant differences using the Excel application; a complex comparison of the samples was performed using discriminant canonical analysis using the STATISTICA 6.0 software package.

\section{Results}

\subsection{Morphometry}

The phenotypic traits of the lizards have a high level of variability, some of them is associated with the ecological and geographical features of the localities of capture. So, in particular, it is known that lizards become larger when moving to the south of the range. In this regard, it could be expected that between the lizards of the village Verkhnekardail'skiy and the village Yamnoye, fewer statistically significant differences would be found than when comparing the lizards of these two localities with the lizards of the Stavropol Territory, the latter being superior to the lizards of the first two localities in morphometric characteristics.

In order to test these assumptions, a comparative analysis of individuals of the Stavropol Upland and the village Verkhnekardail'skiy was carried out; statistically significant differences were revealed for 11 morphometric characters and 2 indices (Table 2).

Table 2. Morphometric parameters of lizards of the Stavropol Territory and the village Verkhnekardail'skiy.

\begin{tabular}{|c|c|c|c|}
\hline \multicolumn{4}{|c|}{$\frac{M \pm m}{\min -m a x}(\mathrm{CV})$} \\
\hline \multirow{2}{*}{ Feature (mm) } & Stavropol & The village & \\
& Territory, $\mathbf{n}=14$ & Verkhnekardail'ski & $\mathbf{P}$ \\
\hline
\end{tabular}




\begin{tabular}{|l|c|c|c|}
\hline L (body length) & $\frac{89,50 \pm 2,55}{74,60-98,40}(10,43)$ & $\frac{78,21 \pm 1,54}{70,40-91,40}(8,15)$ & $* *$ \\
\hline $\begin{array}{l}\text { Pil (the length of } \\
\text { the pileus) }\end{array}$ & $\frac{18,99 \pm 0,46}{16,00-21,90}(8,67)$ & $\frac{16,16 \pm 0,52}{10,50-20,30}(13,21)$ & $* * *$ \\
\hline $\begin{array}{l}\text { L.c (the length of } \\
\text { the head) }\end{array}$ & $\frac{18,24 \pm 0,44}{16,50-21,30}(8,74)$ & $\frac{15,47 \pm 0,49}{10,00-19,20}(13,18)$ & $* * *$ \\
\hline $\begin{array}{l}\text { Lt.c.max (the } \\
\text { maximum width of } \\
\text { the head) }\end{array}$ & $\frac{12,71 \pm 0,44}{10,60-15,90}(12,38)$ & $\frac{9,94 \pm 0,35}{8,10-13,40}(14,62)$ & $* * *$ \\
\hline $\begin{array}{l}\text { Lt.c.oc (the width } \\
\text { of the head between } \\
\text { the supraorbital } \\
\text { scales) }\end{array}$ & $\frac{7,49 \pm 0,14}{7,00-8,90}(6,74)$ & $\frac{6,51 \pm 0,16}{5,50-8,20}(10,28)$ & $* * *$ \\
\hline $\begin{array}{l}\text { Alt.c (head height) } \\
\text { L.an (the length of } \\
\text { the anal scale) }\end{array}$ & $\frac{10,20 \pm 0,30}{8,60-11,80}(10,47)$ & $\frac{7,97 \pm 0,34}{6,50-11,10}(17,74)$ & $* *, 16$ \\
\hline $\begin{array}{l}\text { Lt.an (width of the } \\
\text { anal scale) }\end{array}$ & $\frac{3,12 \pm 0,22}{1,50-4,50}(25,32)$ & $\frac{5,28 \pm 0,11}{1,20-3,30}(20,50)$ & $* * 0,26$ \\
\hline $\begin{array}{l}\text { L.a (the length of } \\
\text { the forelimb) }\end{array}$ & $\frac{28,66 \pm 0,70}{25,10-32,20}(8,78)$ & $\frac{24,68 \pm 0,43}{21,90-28,40}(7,24)$ & $* * *$ \\
\hline $\begin{array}{l}\text { L.p (the length of } \\
\text { the hind limb) }\end{array}$ & $\frac{42,94 \pm 1,35}{36,00-54,10}(11,30)$ & $\frac{35,97 \pm 0,61}{31,80-40,30}(6,70)$ & $* * *$ \\
\hline $\begin{array}{l}\text { L.pes (the length of } \\
\text { the hind foot) }\end{array}$ & $\frac{18,55 \pm 0,66}{16,00-23,60}(12,76)$ & $\frac{16,21 \pm 0,28}{14,70-18,60}(7,00)$ & $* *$ \\
\hline $\begin{array}{l}\text { L.c/Lt.c.max } \\
\text { L.c/Alt.c }\end{array}$ & $\frac{1,44 \pm 0,02}{1,31-1,54}(5,23)$ & $\frac{1,56 \pm 0,04}{1,06-1,74}(9,89)$ & $* *$ \\
\hline
\end{tabular}

Hereinafter:

$* * *$ - differences are statistically significant at $\mathrm{P} \leq 0.001$;

$* *$ - differences are statistically significant at $\mathrm{P} \leq 0.01$;

$*$ - differences are statistically significant at $\mathrm{P} \leq 0.05$.

Statistically significant differences in 10 morphometric characters and 4 indices were revealed between all individuals of the Stavropol Upland and the village Yamnoye (Table $3)$.

Table 3. Indicators of morphometry of lizards of the Stavropol Territory and the village Yamnoye.

\begin{tabular}{|c|c|c|c|}
\hline \multicolumn{4}{|c|}{$\frac{\mathrm{M} \pm \mathrm{m}}{\min -\mathrm{max}}(\mathrm{CV})$} \\
\hline Feature (mm) & $\begin{array}{c}\text { The Stavropol } \\
\text { Territory, } \\
\mathbf{n}=\mathbf{1 4}\end{array}$ & $\begin{array}{c}\text { The village } \\
\text { Yamnoye, } \mathbf{n = 1 2}\end{array}$ & P \\
\hline
\end{tabular}




\begin{tabular}{|c|c|c|c|}
\hline L (body length) & $\frac{89,50 \pm 2,55}{74,60-98,40}(10,43)$ & $\frac{81,46 \pm 1,46}{70,70-89,40}(5,95)$ & $*$ \\
\hline $\begin{array}{l}\text { Pil (the length of the } \\
\text { pileus) }\end{array}$ & $\frac{18,99 \pm 0,46}{16,00-21,90}(8,67)$ & $\frac{15,88 \pm 0,77}{10,50-18,30}(16,13)$ & $* *$ \\
\hline $\begin{array}{l}\text { L.c (the length of the } \\
\text { head) }\end{array}$ & $\frac{18,24 \pm 0,44}{16,50-21,30}(8,74)$ & $\frac{14,92 \pm 0,76}{9,10-17,10}(16,98)$ & $* * *$ \\
\hline $\begin{array}{l}\text { Lt.c.max (the } \\
\text { maximum width of } \\
\text { the head) }\end{array}$ & $\frac{12,71 \pm 0,44}{10,60-15,90}(12,38)$ & $\frac{10,65 \pm 0,44}{8,70-12,50}(13,66)$ & $* *$ \\
\hline $\begin{array}{l}\text { Lt.c.oc (the width of } \\
\text { the head between the } \\
\text { supraorbital scales) }\end{array}$ & $\frac{7,49 \pm 0,14}{7,00-8,90}(6,74)$ & $\frac{6,62 \pm 0,17}{5,80-7,40}(8,27)$ & $* * *$ \\
\hline Alt.c (head height) & $\frac{10,20 \pm 0,30}{8,60-11,80}(10,47)$ & $\frac{8,70 \pm 0,46}{6,40-11,40}(17,62)$ & $*$ \\
\hline $\begin{array}{l}\text { L.an (the length of } \\
\text { the anal scale) }\end{array}$ & $\frac{6,76 \pm 0,16}{5,60-7,50}(8,33)$ & $\frac{5,71 \pm 0,32}{4,40-7,60}(18,59)$ & $* *$ \\
\hline $\begin{array}{l}\text { L.a (the length of the } \\
\text { forelimb) }\end{array}$ & $\frac{28,66 \pm 0,70}{25,10-32,20}(8,78)$ & $\frac{24,01 \pm 0,53}{22,60-28,60}(7,28)$ & $* * *$ \\
\hline $\begin{array}{l}\text { L.p (the length of the } \\
\text { hind limb) }\end{array}$ & $\frac{42,94 \pm 1,35}{36,00-54,10}(11,30)$ & $\frac{35,60 \pm 0,91}{31,80-40,30}(8,49)$ & $* * *$ \\
\hline $\begin{array}{l}\text { L.pes (the length of } \\
\text { the hind foot) }\end{array}$ & $\frac{18,55 \pm 0,66}{16,00-23,60}(12,76)$ & $\frac{16,23 \pm 0,38}{13,80-18,30}(7,00)$ & $* *$ \\
\hline L./L.c. & $\frac{4,85 \pm 0,15}{3,88-5,70}(11,24)$ & $\frac{5,62 \pm 0,34}{4,60-8,56}(20,18)$ & $*$ \\
\hline L./L.a. & $\frac{3,09 \pm 0,09}{2,43-3,72}(10,75)$ & $\frac{3,40 \pm 0,07}{3,01-3,80}(6,96)$ & $*$ \\
\hline L./L.p. & $\frac{2,07 \pm 0,06}{1,60-2,38}(11,29)$ & $\frac{2,30 \pm 0,04}{2,01-2,32}(6,07)$ & $* *$ \\
\hline L.p./L.cru. & $\frac{3,98 \pm 0,14}{3,17-5,06}(12,69)$ & $\frac{3,48 \pm 0,08}{3,01-3,68}(7,64)$ & $* *$ \\
\hline
\end{tabular}

According to all these features, the lizards of the Stavropol Territory surpass the lizards of the village Verkhnekardail'skiy and the village Yamnoye, characterized by large body sizes, limb length, anal shield length and width, as well as a massive head based on indices, which corresponds to an increase in body weight and size of lizards in the south of the range.

Statistically significant differences in 1 morphometric trait and 3 indices were found between all individuals of the village Verkhnekardail'skiy and the village Yamnoye (Table 4). At the same time, the characters, when comparing which statistically significant differences were revealed between the lizards of the village Verkhnekardail'skiy and the village Yamnoye, were not involved in the differentiation of lizards in the Stavropol Territory and the village Yamnoye. 
Table 4. Indicators of morphometry of lizards from the village Yamnoye and the village Verkhnekardail'skiy.

\begin{tabular}{|l|c|c|c|}
\hline \multicolumn{4}{|c|}{$\frac{\mathrm{M} \pm \mathrm{m}}{\text { min-max }}(\mathrm{CV})$} \\
\hline \multicolumn{1}{|c|}{ Feature (mm) } & $\begin{array}{c}\text { The village } \\
\text { Verkhnekardail'skiy, } \\
\mathbf{n = 1 8}\end{array}$ & $\begin{array}{c}\text { The village } \\
\text { Yamnoye, } \mathbf{n = 1 2}\end{array}$ & P \\
\hline $\begin{array}{l}\text { Lt.an (width of the } \\
\text { anal scale) }\end{array}$ & $\frac{2,28 \pm 0,11}{1,20-3,30}(20,50)$ & $\frac{2,82 \pm 0,09}{2,40-3,40}(10,58)$ & $* * *$ \\
\hline L.c/Lt.c.max & $\frac{1,56 \pm 0,04}{1,06-2,74}(9,89)$ & $\frac{1,40 \pm 0,06}{1,02-1,55}(13,41)$ & $*$ \\
\hline L.c./Alt.c & $\frac{1,96 \pm 0,05}{1,54-2,27}(9,73)$ & $\frac{1,75 \pm 0,09}{1,31-2,11}(16,63)$ & $*$ \\
\hline L./L.a & $\frac{3,17 \pm 0,05}{2,75-3,68}(6,97)$ & $\frac{3,40 \pm 0,07}{3,01-3,80}(6,96)$ & $*$ \\
\hline
\end{tabular}

Analyzing the data in Table 4, we can conclude that the lizards of the village Yamnoye have a wider anal shield, but a smaller ratio of the length of the head to its width and height, while the ratio of body length to the length of the forelimb in the lizards of the village Yamnoye was greater than that of the lizards of the village Verkhnekardail'skiy. That is, the lizards of the village Yamnoye have less long forelimbs and a shorter head than the lizards of the village Verkhnekardail'skiy.

When analyzing sexual dimorphism by morphometric characters, we revealed statistically significant differences between females and males both in lizards of the Stavropol Territory and in the village Yamnoye (Table 5). The sexual dimorphism wasn't found on morphometric characters in the lizard populations of the farm of the village Verkhnekardail'skiy.

Table 5. Morphometric parameters of females and males of the sand lizard.

\begin{tabular}{|l|c|c|c|}
\hline \multicolumn{2}{|c|}{$\frac{\mathrm{M} \pm \mathrm{m}}{\mathrm{min}-\mathrm{max}}(\mathrm{CV})$} \\
\hline $\begin{array}{c}\text { The Stavropol } \\
\text { Territory }\end{array}$ & Females & Males & P \\
\hline L/L.c. & $\frac{5,18 \pm 0,10}{4,83-5,41}(4,66)$ & $\frac{4,53 \pm 0,29}{3,89-5,70}(12,98)$ & $*$ \\
\hline $\begin{array}{l}\text { L/L.p. } \\
\text { The village } \\
\text { Yamnoye }\end{array}$ & $\frac{2,20 \pm 0,53}{2,05-2,37}(5,87)$ & $\frac{1,94 \pm 0,12}{1,60-2,38}(12,83)$ & $*$ \\
\hline $\begin{array}{l}\text { Lt.c.max (the } \\
\text { maximum width of } \\
\text { the head) }\end{array}$ & $\frac{9,38 \pm 0,33}{8,70-10,40}(7,90)$ & $\frac{11,92 \pm 0,23}{11,20-12,60}(4,23)$ & $* * *$ \\
\hline $\begin{array}{l}\text { Lt.c.oc (the width of } \\
\text { the head between the } \\
\text { supraorbital scales) }\end{array}$ & $\frac{6,25 \pm 0,23}{5,80-7,10}(8,14)$ & $\frac{6,98 \pm 0,12}{6,60-7,40}(3,99)$ & $*$ \\
\hline
\end{tabular}




\begin{tabular}{|l|c|c|c|}
\hline Alt.c (head height) & $\frac{7,57 \pm 0,49}{6,40-9,60}(14,45)$ & $\frac{9,83 \pm 0,42}{8,60-11,40}(9,60)$ & $* *$ \\
\hline $\begin{array}{l}\text { L.an (the length of the } \\
\text { anal scale) }\end{array}$ & $\frac{4,82 \pm 0,14}{4,40-5,10}(6,62)$ & $\frac{6,60 \pm 0,31}{5,70-7,60}(10,37)$ & $* * *$ \\
\hline $\begin{array}{l}\text { L.p (the length of the } \\
\text { hind limb) }\end{array}$ & $\frac{33,17 \pm 1,05}{30,70-36,20}(7,10)$ & $\frac{38,03 \pm 0,26}{37,20-38,70}(1,55)$ & $* * *$ \\
\hline $\begin{array}{l}\text { L.cru (the length of } \\
\text { the lower leg of the } \\
\text { hind limb) }\end{array}$ & $\frac{9,43 \pm 0,33}{8,50-10,40}(7,78)$ & $\frac{11,15 \pm 0,52}{10,00-12,50}(10,38)$ & $*$ \\
\hline L.an./Lt.an & $\frac{1,70 \pm 0,10}{1,35-1,96}(13,28)$ & $\frac{2,39 \pm 0,08}{2,17-2,57}(7,84)$ & $* * *$ \\
\hline
\end{tabular}

Based on the evaluated morphometric characters, a two-factor discriminant analysis (as the first factor, we chose the locality of animals, morphometric characteristics as the second) of their variability in lizards of different localities was performed (Fig. 2).

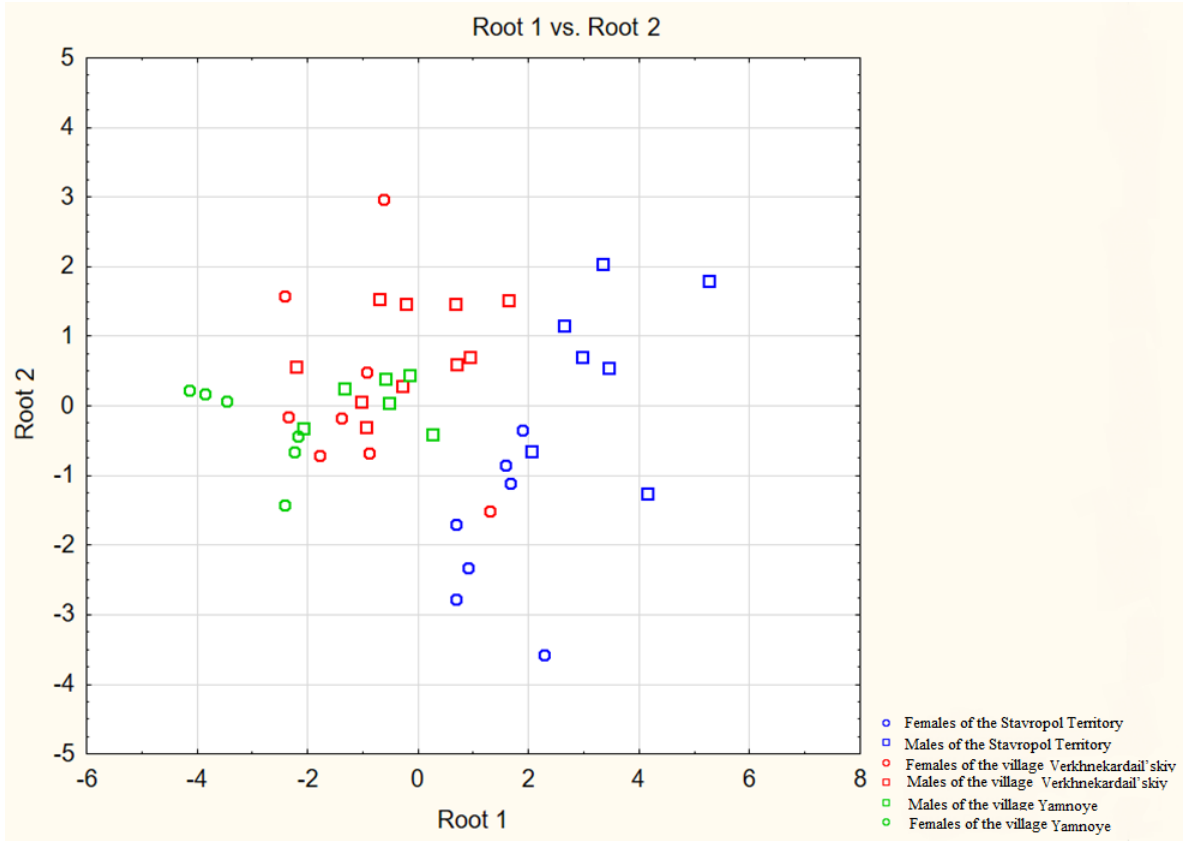

Fig. 2. Location of the studied individuals of the sand lizard in the space of two discriminant functions.

The data presented in Fig. 2, allow us to conclude that the lizards of the three localities are separated in the space of two discriminant functions for all the studied morphometric features. The first of them (Root 1) differentiates males and females from the village Yamnoye and the farmstead of the village Verkhnekardailskiy, on the one hand, and males and females from the Stavropol Territory, on the other. At the same time, the second function (Root 2) also separates these groups. The lizards of the Stavropol Territory are distinguished by a relatively large spread in the space of two functions than the lizards of the village Verkhnekardail'skiy and the village Yamnoye (Fig. 2).

Based on the analyzed morphometric parameters, the Mahalanobis distances between groups of lizards were calculated. The values of the distances (Table 6) indicate that 
according to them, sexual dimorphism is most pronounced in the lizards of the village Yamnoye, least of all in the lizards of the village Verkhnekardail'skiy, which is also confirmed by the number of characters that distinguish these groups of animals from each other (Table 5).

Table 6. Distances of Mahalanobis between groups of lizards by morphometric characteristics.

\begin{tabular}{|c|l|c|}
\hline $\begin{array}{c}\text { Groups of } \\
\text { lizards }\end{array}$ & \multicolumn{1}{|c|}{ Compared territories } & $\begin{array}{c}\text { Distances of } \\
\text { Mahalanobis }\end{array}$ \\
\hline \multirow{3}{*}{ Females/males } & The Stavropol Territory & 11,06 \\
\cline { 2 - 3 } & The village Verkhnekardailskiy & 2,39 \\
\cline { 2 - 3 } & The village Yamnoye & 11,32 \\
\hline \hline \multirow{3}{*}{ Females/females } & The Stavropol Territory / The village Verkhnekardailskiy & 11,33 \\
\cline { 2 - 3 } & The Stavropol Territory / The village Yamnoye & 23,59 \\
\cline { 2 - 3 } & The village Verkhnekardailskiy / The village Yamnoye & 8,06 \\
\hline \hline \multirow{3}{*}{ Males/males } & The Stavropol Territory / The village Verkhnekardailskiy & 14,31 \\
\cline { 2 - 3 } & The Stavropol Territory / The village Yamnoye & 21,69 \\
\cline { 2 - 3 } & The village Verkhnekardailskiy / The village Yamnoye & 8,36 \\
\hline
\end{tabular}

The largest values of the distances between females of the sand lizard are observed when comparing animals from the Stavropol Territory and the village Yamnoye, the smallest - when comparing lizards from the village Verkhnekardail'skiy and the village Yamnoye. A similar picture is observed when comparing the males of the sand lizard. The distance between the females of lizards from the village Yamnoye and the Stavropol Territory was greater than between the males.

\subsection{Scale cover}

When analyzing the indicators of scaling of lizards in the Stavropol Territory and the village Yamnoye, statistically significant differences were revealed in 5 characteristics, between the lizards of the village Verkhnekardail'skiy and the village Yamnoye - in 7 characteristics (Table 7). The value of the coefficient of variation (CV) reached the lowest values in the lizards of the village Yamnoye for most of the characters.

Between the lizards of the Stavropol Territory and the farmstead of the village Verkhnekardail'skiy, no statistically significant differences were found in terms of scaling.

Table 7. Indicators of scaling of lizards of the studied localities.

\begin{tabular}{|l|c|c|c|}
\hline \multicolumn{3}{|c|}{$\frac{\mathrm{M} \pm \mathrm{m}}{\mathrm{m} \pm \mathrm{m}-\mathrm{max}}(\mathrm{CV})$} \\
\hline Feature (mm) & $\begin{array}{c}\text { The village } \\
\text { Yamnoye, } \mathrm{n}=\mathbf{1 2}\end{array}$ & $\begin{array}{c}\text { The } \\
\text { Stavropol } \\
\text { Territory, } \\
\mathbf{n}=\mathbf{1 4}\end{array}$ & P \\
\hline $\begin{array}{l}\text { Lab. (number of supralabial plates } \\
\text { in front of the infraorbital plate on } \\
\text { the left and right) }\end{array}$ & $\frac{4,04 \pm 0,04}{4,00-5,00}(5,05)$ & $\frac{4,32 \pm 0,09}{4,00-5,00}(11,00)$ & $* *$ \\
\hline $\begin{array}{l}\text { P.p. (number of trunk scales along } \\
\text { the posterior margin of the pileus) }\end{array}$ & $\frac{13,83 \pm 0,34}{12,00-16,00}(8,06)$ & $\frac{15,50 \pm 0,50}{14,00-18,00}(11,5 \neq)$ & $* *$ \\
\hline $\begin{array}{l}\text { D.l.p. (the number of subdigital } \\
\text { plates on the fourth toe of the hind } \\
\text { limb on the left and on the right) }\end{array}$ & $\frac{17,79 \pm 0,17}{17,00-20,00}(4,68)$ & $\frac{20,04 \pm 0,38}{18,00-24,00}(9,75)$ & $* * *$ \\
\hline
\end{tabular}




\begin{tabular}{|l|c|c|c|}
\hline $\begin{array}{l}\text { D.l.a. (the number of subdigital } \\
\text { plates on the third finger of the } \\
\text { forelimb on the left and on the } \\
\text { right) }\end{array}$ & $\frac{10,96 \pm 0,17}{9,00-12,00}(7,36)$ & $\frac{11,64 \pm 0,22}{9,00-14,00}(9,70)$ & $* *$ \\
\hline $\begin{array}{l}\text { Feature (mm) } \\
\text { The village } \\
\text { Yamnoye, n=12 }\end{array}$ & $\begin{array}{c}\text { Verkhnekard } \\
\text { ail'skiy, n=18 }\end{array}$ & P \\
\hline $\begin{array}{l}\text { Subtemp. (number of inferior } \\
\text { temporal scutes on the left and on } \\
\text { the right) }\end{array}$ & $\frac{7,00 \pm 0,18}{5,00-8,00}(12,64)$ & $\frac{6,33 \pm 0,15}{5,00-8,00}(14,12)$ & $* *$ \\
\hline $\begin{array}{l}\text { P.p. (number of trunk scales along } \\
\text { the posterior margin of the pileus) }\end{array}$ & $\frac{13,83 \pm 0,34}{13,00-16,00}(8,06)$ & $\frac{15,31 \pm 0,18}{13,00-18,00}(8,16)$ & $*$ \\
\hline $\begin{array}{l}\text { PN (number of posterior nasal } \\
\text { pads on the left and right) }\end{array}$ & $\frac{1,92 \pm 0,06}{1,00-2,00}(14,73)$ & $\frac{1,72 \pm 0,08}{1,00-2,00}(26,38)$ & $*$ \\
\hline $\begin{array}{l}\text { Fren. (the number of anterior } \\
\text { zygomatic scutes on the left and } \\
\text { right) }\end{array}$ & $\frac{1,64 \pm 0,08}{1,00-2,00}(29,72)$ & $\frac{1,29 \pm 0,14}{0,00-2,00}(53,44)$ & $* *$ \\
\hline $\begin{array}{l}\text { D.l.p (the number of subdigital } \\
\text { plates on the fourth toe of the hind } \\
\text { limb on the left and on the right) }\end{array}$ & $\frac{17,79 \pm 0,17}{17,00-21,00}(4,68)$ & $\frac{19,44 \pm 0,03}{17,00-20,00}(5,25)$ & $* * *$ \\
\hline $\begin{array}{l}\text { D.l.a (the number of subdigital } \\
\text { plates on the third finger of the } \\
\text { forelimb on the left and on the } \\
\text { right) }\end{array}$ & $\frac{10,96 \pm 0,13}{10,00-13,00}(6,69)$ & $\frac{10,96 \pm 0,17}{9,00-12,00}(7,36)$ & $*$ \\
\hline
\end{tabular}

Based on the assessed signs of scaling, a two-factor discriminant analysis (as the first factor, we chose the locality of animals, characteristics of the scaly cover as the second) of their variability in lizards of different localities was performed (Fig. 3).

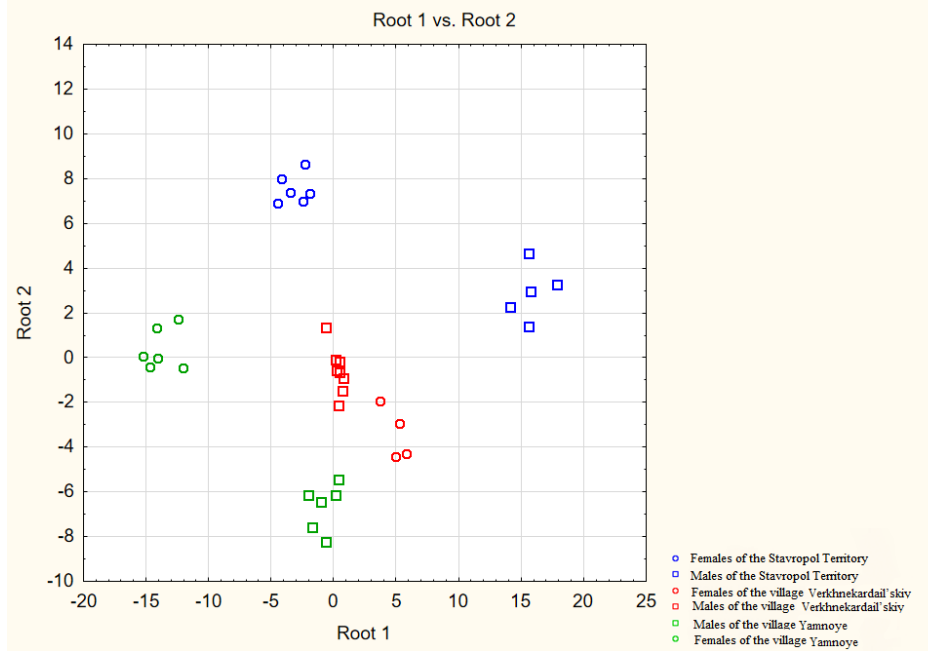

Fig. 3. Location of a sand lizard in the space of two discriminant functions.

In fig. 3 shows the results of discriminant analysis. Considering the distribution of individuals of the sand lizard in the space of two discriminant functions (Root 1 and Root 2), attention is drawn to the separation of males and females of lizards from the village Yamnoye and the Stavropol Territory, which is noticeably less pronounced in the lizards of 
the village Verkhnekardail'skiy, despite the fact that pronounced sexual dimorphism it was not found in lizards from the village Yamnoye by signs of scaling (Table 9).

The calculation of the Mahalanobis distances was carried out according to the parameters of lizard scaling (Table 8). The data obtained indicate that sexual dimorphism is most pronounced in lizards of the Stavropol Territory, least of all in lizards of the village Verkhnekardail'skiy. Distances between males of three localities exceeded the distances between females. The exception was the distances between the females of the village Verkhnekardail'skiy and the village Yamnoye, which exceeded the values of the distances between males of the same localities.

Tables 8. Distances of Mahalanobis between groups of lizards according to signs of scaling.

\begin{tabular}{|c|l|c|}
\hline $\begin{array}{c}\text { Groups of } \\
\text { lizards }\end{array}$ & \multicolumn{1}{|c|}{ Compared territories } & $\begin{array}{c}\text { Distances of } \\
\text { Mahalanobis }\end{array}$ \\
\hline \multirow{3}{*}{ Females/males } & The Stavropol Territory & 368,35 \\
\cline { 2 - 3 } & The village Verkhnekardailskiy & 76,48 \\
\cline { 2 - 3 } & The village Yamnoye & 226,58 \\
\hline \hline \multirow{3}{*}{ Females/females } & The Stavropol Territory / The village Verkhnekardailskiy & 206,17 \\
\cline { 2 - 3 } & The Stavropol Territory / The village Yamnoye & 174,92 \\
\cline { 2 - 3 } & The village Verkhnekardailskiy / The village Yamnoye & 389,18 \\
\hline \hline \multirow{3}{*}{ Males/males } & The Stavropol Territory / The village Verkhnekardailskiy & 265,75 \\
\cline { 2 - 3 } & The Stavropol Territory / The village Yamnoye & 372,57 \\
\cline { 2 - 3 } & The village Verkhnekardailskiy / The village Yamnoye & 50,98 \\
\hline
\end{tabular}

When assessing the severity of sexual dimorphism in terms of scaling, we found statistically significant differences between males and females in the populations of the Stavropol Territory and the village Verkhnekardail'skiy (Table 9). Between the females and males of lizards from the village Yamnoye, no sexual dimorphism was found in terms of scaling, which can also be associated with a reduced diversity of the scaly cover in lizards in disadvantaged areas of the range, since the village Yamnoye is a forest-steppe and is located $9 \mathrm{~km}$ from the city of Voronezh and $5 \mathrm{~km}$ from the airport.

Table 9. Indicators of scaling of females and males of the sand lizard.

\begin{tabular}{|l|c|c|c|}
\hline \multicolumn{2}{|c|}{$\frac{\mathrm{M} \pm \mathrm{m}}{\min -\mathrm{max}}(\mathrm{CV})$} & Males, n=7 & P \\
\hline The Stavropol Territory & Females, n=7 & $\frac{21,14 \pm 0,50}{18,00-24,00}(8,62)$ & $* *$ \\
\hline $\begin{array}{l}\text { D.l.p (the number of subdigital } \\
\text { plates on the fourth toe of the hind } \\
\text { limb on the left and on the right) }\end{array}$ & $\frac{18,93 \pm 0,33}{18,00-22,00}(6,37)$ & $\frac{12,15 \pm 0,33}{10,00-14,00}(9,41)$ & $*$ \\
\hline $\begin{array}{l}\text { D.l.a (the number of subdigital } \\
\text { plates on the third finger of the } \\
\text { forelimb on the left and on the } \\
\text { right) }\end{array}$ & $\frac{11,14 \pm 0,26}{9,00-12,00}(8,52)$ & $\frac{28,40 \pm 0,45}{28,00-30,00}(3,15)$ & $*$ \\
\hline $\begin{array}{l}\text { Vent (number of transverse rows of } \\
\text { abdominal scutes, including } \\
\text { thoracic) }\end{array}$ & $\frac{30,14 \pm 0,37}{29,00-31,00}(2,98)$ & Males, n=10 & Phe village \\
\hline \multicolumn{1}{|c|}{ Verkhnekardail'skiy } & Females, n=8 & $\frac{44,40 \pm 1,07}{40,00-49,00}(7,22)$ & $*$ \\
\hline $\begin{array}{l}\text { Sq (number of rows of dorsal scales } \\
\text { in the middle of the body) }\end{array}$ & $\frac{41,12 \pm 1,00}{38,00-45,00}(6,43)$ & & $*$ \\
\hline
\end{tabular}




\begin{tabular}{|l|l|l|l|}
\hline $\begin{array}{l}\text { Lab.a (number of supralabial plates } \\
\text { in front of the infraorbital plate on } \\
\text { the left and right) }\end{array}$ & $\frac{4,00 \pm 0,00}{4,00-4,00}(0,00)$ & $\frac{4,35 \pm 0,11}{4,00-5,00}(11,23)$ & $* *$ \\
\hline
\end{tabular}

\section{Discussion}

The greatest number of statistically significant differences in morphometric characters was found when comparing lizards of the Stavropol Territory with lizards from the village Verkhnekardail'skiy and the village Yamnoye, between which there were significantly fewer statistically significant differences for the same characters (Tables 2-4). Sexual dimorphism in terms of morphometric characters is most pronounced in lizards of the locality with the highest anthropogenic load - the village Yamnoye; 7 statistically significant differences were found between females and males of lizards, while only 2 differences in indices were revealed between males and females of lizards of the Stavropol Territory. In the lizards of the village Verkhnekardail'skiy, there were no sex differences in morphometric characteristics.

The lizards of the southernmost locality - Stavropol Territory - as expected, surpassed in morphometric parameters the lizards of other studied localities located much to the north (the village Verkhneardailsky is located $631 \mathrm{~km}$, the village Yamnoye is $771 \mathrm{~km}$ from the collection points of lizards in the Stavropol Territory).

Based on the values of the standardized coefficients of discriminant functions, we identified the following characters most involved in the sex and intergroup differences in lizards: L. (body length), Lt.c.max (maximum head width), Lt.c.oc. (width of the head at the level of the centers of the eyes), L.an. (length of the anal shield). For all these characters, statistically significant differences were found between the lizards of the village Verkhnekardail'skiy, the village Yamnoye and the Stavropol Territory. Between the lizards of the village Verkhnekardalsky and the village Yamnoye, differences were also found in another characteristic - Lt.an. This may indicate that the morphometric characters involved in the differentiation of individuals of the sand lizard along the north - south axis and due to the proximity of large cities are different.

In turn, when analyzing the indicators of scaling of lizards of the Stavropol Territory and the village Yamnoye, statistically significant differences were found between them in 5 characteristics, between lizards of the village Verkhnekardail'skiy and the village Yamnoye - according to 7 characteristics, between the lizards of the Stavropol Territory and the village Verkhnekardail'skiy, statistically significant differences were revealed in nonscaling indicators It was. When assessing the severity of sexual dimorphism in terms of fluttering, statistically significant differences between males and females were observed between groups of lizards in the Stavropol Territory and the village Verkhnekardail'skiy. Between the females and males of lizards from the village Yamnoye, there was no sexual dimorphism in terms of scaly cover (Table 9).

\section{Conclusion}

According to literature data, sexual dimorphism in various animals becomes more pronounced under unfavorable conditions, where a relatively increased evolutionary plasticity of the population is required $[24,25]$. In the lizards of the village Yamnoye, sexual dimorphism is much more pronounced than in the lizards of the Stavropol Territory and the village Verkhnekardail'skiy, which may indicate the disadvantage of this locality, located $9 \mathrm{~km}$ from the city of Voronezh and $5 \mathrm{~km}$ from the airport. It should be noted that the characters involved in sexual differentiation in lizards of the Stavropol Territory and the 
village Yamnoye are different (Table 5). This may indicate that each environmental factor has its own preferred target of action for the object under study.

It is known that the increase in the diversity of the scaly cover in the steppe populations of lizards is associated with a number of traits with climatic factors, the effect of which is formed during the incubation of eggs and the development of embryos [19-22]. In addition, the loss of the polymerization of the scaly cover may be associated with the relative ecological disadvantage of the locality occupied by the lizards. This can explain the low coefficient of variation in the lizards of the village Yamnoye, which is experiencing the greatest anthropogenic pressure due to the proximity to the large city of Voronezh and the airport, as well as the absence of statistically significant differences in the signs of pholidosis between the lizards of the village Vekhnekardailsky and Stavropol Territories (Table 7,9), since the natural zone of the village Yamnoye is represented by forest-steppe, and the natural zones of the farmstead of the village Verkhnekardail'skiy Volgograd region and the villages of Poperechnyy and Sredniy Stavropol Territory - the steppe.

In general, our data indicate the specific features of the response of phenotypic traits to the action of various environmental factors on the studied animals, in particular, on the population of the sand lizard.

\section{References}

1. J. Axelsson, E. Wapstra, E. Miller, N. Rollings, M. Olsson, Scientific Reports (2020)

2. P. Borodin, CompCytogen, 10, 3 (2016)

3. D. J. Harris, E. N. Arnold, R. H. Thomas, Proceedings: Biological Sciences, 265 (2014)

4. P. Lisachov, M. Giovannotti, J. C. Pereira, D. A. Andreyushkova, S. A. Romanenko, M. A. Ferguson-Smith, P. M. Borodin, V. A. Trifonov, Cytogenet Genome Res. (2020)

5. E. S. Roitberg, G. V. Eplanova, T. I. Kotenko, F. Ama, M. A. Carretero, V. N. Kuranova, N. A. Bulakhova, O. I. Zinenko, V. A. Yakovlev, Journal of evolutionary biology, 28 (2015)

6. A Sand Lizard (Nauka, Moscow, 1976)

7. G.F. Suchow, Proceedings of the Zoological Institute of the Academy of Scienses of the (USSR, 1948)

8. P.V. Terentjev, S.A. Chernov, Guid-book on Reptiles and Amphibians (Sovetskaya nauka, Moscow, 1949)

9. M. A. Chirikova, V. M. Dubjansky, T. N. Dujsebayeva (SQUAMATA, LACERTIDAE, 2001)

10. S.A. Kalyabina-Hauf, N.B. Ananjeva, Proceedings of the Zoological Institute, 302 (2004)

11. V. P. Korneychuk, M. A. Chirikova, Modern herpetology (2005)

12. E. P. Simonov, Modern herpetology, 8 (2007)

13. E. P. Simonov, Samara Luka: problems of regional and global ecology, 18, 1 (2009)

14. V. N. Peskov, E. Yu. Sviridenko, A. Yu. Mlyuk, T. I. Kotenko, Scientific Bulletin of Uzhgorod University Biology Series, 27 (2010)

15. Y. Malysh, Proceedings of the Ukrainian Herpetological Society, 5 (2014)

16. G.V. Eplanova, E.S. Roitberg, Amphibia-Reptilia, 36, 3 (2015)

17. I. Bolnyh, O. N. Zhigileva, Color polymorphism and genetic variability of the sand lizard (lacerta agilis) (LACERTIDAE, SAURIA) the environs of the cities of Tyumen and Sterlitamak, 16 (2015)

18. Z. P. Honyakina, Z. A. Ferkhatova, Questions of herpetology (1977)

19. V. M. Zakharov, Questions of herpetology (1981) 
20. E. S. Roitberg, Questions of herpetology (1981)

21. E. S. Roitberg, Questions of herpetology (1989)

22. Y. Malyuk, V. N. Peskov, Collection of works of the Zoological Museum, 42 (2011)

23. O.V. Kukushkin, O.A. Ermakov, A.Yu. Ivanov, I.V. Doronin, E.Yu. Sviridenko, E.P. Simonov, R.A. Gorelov, M.A. Khramova, I.G. Blokhin, Proceedings of the Zoological Institute of the Russian Academy of Sciences, 324, 1 (2020)

24. V. A. Geodakyan, Evolutionary logic of sex differentiation in phylogeny and ontogenesis6 abstract of the dissertation of the Doctor of Biological Sciences (1987)

25. N. A. Bulakhova, V. N. Kuranova, S. V. Savelyev, Siberian Zoological Conference dedicated to the 60th anniversary of the Institute of Systematics and Ecology of Animals (Novosibirsk, 2004) 